\title{
PENERAPAN PEMBELAJARAN KOOPERATIF TIPE TEAM ASSISTED INDIVIDUALIZATION (TAI) UNTUK MENINGKATKAN AKTIVITAS DAN PRESTASI BELAJAR IPA PADA SISWA KELAS VI SD NEGERI 3 PENATIH
}

\author{
I Dewa Ayu Putu Suryati \\ SD Negeri 1 Penatih \\ Agusbali742@yahoo.com
}

\begin{abstract}
ABSTRAK
Penelitian Tindakan Kelas (PTK) ini bertujuan untuk meningkatkan prestasi belajar IPA dengan menerapkan pembelajaran Team Assisted Individualization (TAI) pada siswa kelas VI SDN 3 Penatih. Subjek penelitian ini adalah siswa kelas VI SDN 3 Pelatih Kabupaten Denpasar Timur, Kota Denpasar 2016/2017 pada semester pertama (tidak datar) dengan 36 siswa, yang terdiri dari 18 siswa laki-laki dan 18 siswa perempuan. Data diperoleh / dikumpulkan dalam bentuk data yang langsung direkam selama pembelajaran di kelas. Penelitian ini melalui dua tahap atau siklus, setiap siklus mengandung empat langkah, yaitu: (1) perencanaan, (2) implementasi tindakan, (3) observasi dan evaluasi tindakan, dan (4) refleksi. Hipotesis dalam penelitian ini dianalisis secara deskriptif, yaitu menganalisis nilai rata-rata kemampuan afektif dan kognitif siswa secara klasik.
\end{abstract}

\section{Kata Kunci: Cooperative TAI type, Aktivitas Belajar, Prestasi Belajar}

\begin{abstract}
This Classroom Action Research (CAR) aims to improve science learning achievement by applying Team Assisted Individualization (TAI) learning to class VI SDN 3 Penatih students. The subjects of this study were grade VI students of SDN 3 Coaches East Denpasar District, Denpasar City 2016/2017 in the first semester (odd) with 36 students, consisting of 18 male students and 18 female students. Data obtained/collected in the form of data directly recorded during classroom learning. This research through two stages or cycles, each cycle contains four steps, namely: (1) planning, (2) implementation of actions, (3) observation and evaluation of actions, and (4) reflection. The hypothesis in this study was analyzed descriptively, namely analyzing the average value of affective and cognitive abilities of students in a classical manner.
\end{abstract}

Keywords: Cooperative TAI type, Learning Activity, Learning Achievement

\section{PENDAHULUAN}


Ilmu Pengetahuan Alam (IPA) sering disebut dengan ilmu Sains. IPA berkaitan dengan cara mencari tahu tentang gejala alam secara sistematis, sehingga IPA bukan hanya penguasaan kumpulan pengetahuan yang berupa fakta-fakta, konsep-konsep, atau prinsip-prinsip saja tetapi juga merupakan suatu proses penemuan. Pendidikan IPA diharapkan dapat menjadi wahana bagi peserta didik untuk mempelajari diri sendiri dan alam sekitar, serta prospek pengembangan lebih lanjut dalam menerapkannya dalam kehidupan sehari-hari. Proses pembelajarannya menekankan pada pemberian pengalaman langsung untuk mengembangkan kompetensi agar peserta didik mampu menjelajahi dan memahami alam sekitar secara ilmiah.

Pendidikan IPA diarahkan untuk mencari tahu dan berbuat sehingga dapat membantu peserta didik untuk memperoleh pemahaman yang lebih mendalam tentang alam sekitar. Hasil observasi awal yang dilakukan menunjukan bahwa proses pembelajaran IPA di sekolah selama ini terlihat kurang menarik, sehingga siswa merasa jenuh dan kurang memiliki minat pada pelajaran IPA. Hal ini akan berimplikasi pada suasana kelas cenderung pasif, sedikit sekali siswa yang bertanya pada guru meskipun materi yang diajarkan belum dapat dipahami. Keadaan demikian menimbulkan kejengkelan, kebosanan, sikap masa bodoh, sehingga perhatian, minat, dan motivasi siswa dalam pembelajaran menjadi rendah. Hal ini akan berdampak terhadap ketidaktercapaian tujuan pembelajaran IPA.

Sebagai bahan kajian yang bersifat praktis, prestasi belajar IPA yang dicapai oleh siswa kelas VI SDN 3 Penatih pada semester 1 Tahun pelajaran 2016/2017 belum optimal dan perlu di tingkatkan. Hal ini terlihat dari rata-rata prestasi belajar yang dicapai siswa 56,67. Kriteria Ketuntasan Minimal (KKM) yang ditetapkan adalah 60 dengan kentuntasan yang dicapai $56 \%$. Untuk lebih jelasnya disajikan data pada tabel 1.1 berikut ini.

Tabel 1.1.

Nilai Tes Formatif Mata Pelajaran IPA Kls VI SDN 3 Penatih

\begin{tabular}{clc}
\hline No. & \multicolumn{1}{|c}{ Uraian Pencapaian Hasil } & $\begin{array}{c}\text { Banyak } \\
\text { Siswa }\end{array}$ \\
\hline 1 & Siswa yang mendapat nilai di bawah 60 & 16 \\
2 & Siswa yang mendapat nilai di atas 60 & 20 \\
3 & Rata-rata & 56,67 \\
4 & \% Ketuntasan & $56 \%$ \\
\hline Sumber: Lampiran 3
\end{tabular}


Permasalahan di atas, diduga kuat karena: 1) selama ini guru belum melibatkan siswa dalam pembelajaran IPA, implikasinya siswa menjadi pasif dan kurang bergairah dalam belajar, 2) dikalangan siswa masih muncul kesan materi IPA sangat sulit, abstrak dan kurang menyenangkan serta menakutkan, dan 3) guru belum mampu menggunakan model pembelajaran inovatif sehingga iklim pembelajaran cendrung menotun, dan kurang menarik. Terkait dengan hal tersebut di atas, untuk mencapai tujuan pembelajaran yang telah ditentukan dipandang perlu diupayakan sebuah solusi untuk merubah iklim pembelajaran menjadi lebih baik dari sebelumnya, mengingat begitu pentingnya pembelajaran IPA bagi siswa dalam rangka memberi bekal dan penyiapan generasi yang melek teknologi.

Upaya perbaikan pembelajaran yang dilakukan adalah dengan melaksanakan Penelitian Tindakan Kelas (PTK). PTK adalah penelitian praktis yang dimaksudkan untuk memperbaiki dan atau meningkatkan mutu pembelajaran di kelas. Perbaikan yang dilakukan yaitu dengan penerapan pembelajaran kooperatif tipe Team Assisted Individualization (TAI). Pembelajaran kooperatif Tipe TAI akan melibatkan siswa secara langsung dalam proses pembelajaran. Menurut Slavin, (2005) tipe ini mengkombinasikan keunggulan pembelajaran kooperatif dan pembelajaran individual. Tipe ini dirancang untuk mengatasi kesulitan belajar siswa secara inividual. Melalui Pembelajaran Kooperatif Tipe TAI dalam pembelajaran IPA akan lebih mempermudah bagi guru dalam menyampaikan materi yang akan diajarkan kepada siswa.

Penulis sebagai guru kelas menyadari bahwa selama ini pembelajaran yang dilakukan dikelas masih kurang variatif dan berpusat pada guru, keterlibatan siswa secara langsung dalam proses pembelajaran masih kurang yang mengakibatkan siswa pasif sehingga memengaruhi rendahnya prestasi belajar khususnya pada pelajaran IPA di kelas VI. Hal inilah yang mendorong dan memotivasi penulis untuk melakukan penelitian tindakan kelas dengan topik "Penerapan Pembelajaran Kooperatif tipe Team Assisted Individualization (TAI) Untuk Meningkatkan Aktivitas dan Prestasi Belajar IPA Pada Siswa Kelas VI SD Negeri 3 Penatih. 


\section{KAJIAN PUSTAKA}

\section{Hakikat Prestasi Belajar}

Prestasi belajar berbeda secara prinsipil dengan Hasil belajar. Hasil belajar menunjukkan kualitas jangka waktu yang lebih panjang, misalnya satu cawu, satu semester dan sebagainya. Sedangkan prestasi belajar menunjukkan kualitas yang lebih pendek, misalnya satu pokok bahasan, satu kali ulangan harian dan sebagainya. Pengertian Prestasi adalah hasil yang telah dicapai oleh seseorang setelah melakukan suatu pekerjaan / aktivitas tertentu.

\section{Aktivitas Belajar}

Dimyati dan Mudjiono (1994:106) menyatakan bahwa aktivitas belajar adalah bentuk-bentuk kegiatan yang muncul dalam suatu proses belajar mengajar baik kegiatan fisik yang mudah diamati maupun kegiatan psikis yang sulit diamati. Lebih lanjut dijelaskan kegiatan fisik diantaranya meliputi: membaca, mendengar, menulis, meragakan dan mengukur. Sedangakn kegiatan psikis seperti: mengingat kembali isi pelajaran, menyimpulkan hasil eksperimen, membandingkan suatu konsep dengan konsep lainnya dan sebagainya. Dalam kegiatan pembelajaran siswa dituntut untuk selalu aktif. Aktif memproses dan mengolah belajarnya secara aktif, siswa harus aktif secara fisik, intelektual dan emosional.

\section{Hakikat Pembelajaran IPA (Sains)}

IPA menurut Trowbridge and Bybee (1990) sains atau IPA merupakan representasi dari hubungan dinamis yang mencakup tiga faktor utama yaitu the extant body of scientific knowledge, the values of science and the method and procecces of science yang artinya sains merupakan produk dan proses, serta mengandung nilai-nilai.

Filosofi IPA sebagai cara untuk mencari tahu yang berdasarkan pada observasi. Dengan demikian, pengetahuan dalam IPA merupakan hasil observasi. Kebenaran harus dibuktikan secara empiris berdasarkan observasi atau eksperimen. Pengembangan pembelajaran IPA yang menarik, menyenangkan, layak, sesuai konteks, serta didukung oleh ketersediaan waktu, keahlian, sarana dan prasarana merupakan kegiatan yang tidak mudah untuk dilaksanakan. Seorang guru dituntut memiliki kemampuan dan kreativitas yang cukup agar pembelajaran dapat mencapai tujuan.

\section{Model Pembelajaran Kooperatif}

Model pembelajaran kooperatif adalah rangkaian kegiatan belajar yang dilakukan oleh siswa dalam kelompok-kelompok tertentu untuk mencapai tujuan pembelajaran yang 
telah dirumuskan. Anita Lie (2007:29) mengungkapkan bahwa model pembelajaran cooperative learning tidak sama dengan sekedar belajar dalam kelompok. Ada lima unsur dasar pembelajaran cooperative learning yaitu: saling ketergantungan positif, tanggung jawab perseorangan, tatap muka, komunikasi antar anggota, dan evaluasi proses kelompok. Pembelajaran kooperatif (Cooperative learning) adalah model pembelajaran yang menekankan pada saling ketergantungan positif antar individu siswa, adanya tanggung jawab perseorangan, tatap muka, komunikasi intensif antar siswa, dan evaluasi proses kelompok (Arif Rohman, 2009: 186).

\section{Model Pembelajaran Team Assisted Individualization (TAI)}

Model Pembelajaran kooperatif tipe Team Assisted Individualization (TAI) ini dikembangkan oleh Slavin. Menurut Slavin (2005) tipe ini mengkombinasikan keunggulan pembelajaran kooperatif dan pembelajaran individual. Tipe ini dirancang untuk mengatasi kesulitan belajar siswa secara inividual. Oleh karena itu kegiatan pembelajarannya lebih banyak digunakan untuk pemecahan masalah, ciri khas pada model pembelajaran TAI ini adalah setiap siswa secara individual belajar materi pembelajaran yang sudah dipersiapkan oleh guru. Hasil belajar individual dibawa ke kelompokkelompok untuk didiskusikan dan saling dibahas oleh anggota kelompok, dan semua anggota kelompok bertanggung jawab atas keseluruhan jawaban sebagai tanggung jawab bersama. Pada model pembelajaran TAI ini, akuntabilitas individu, kesempatan yang sama untuk sukses, dan dinamika motivasional menjadi unsur-unsur utama yang harus ditekankan oleh guru.

\section{Kerangka Berpikir}

Pada penelitian ini, Guru menerapkan model kooperatif tipe Team Assisted Individualization (TAI) pada pembelajaran IPA dengan harapan akan dapat meningkatkan minat siswa untuk mengikuti pelajaran, sehingga dapat meningkatkan aktivitas dan prestasi belajar siswa. Penerapan model kooperatif tipe Team Assisted Individualization (TAI) dalam proses pembelajaran mata pelajaran IPA, lebih memberi peluang kepada siswa untuk berpartisipasi aktif dalam proses belajar.

Penelitian ini melalui 2 tahapan atau siklus yang setiap siklus berisi empat langkah yaitu: (1) perencanaan, (2) pelaksanaan tindakan, (3) observasi dan evaluasi tindakan, dan 
(4) Refleksi. Hipotesis dalam penelitian ini dianalisis secara deskriptif, yakni menganalisis nilai rata-rata kemampuan afektif dan kognitif siswa secara klasikal.

\section{Hipotesis Penelitian}

Berdasarkan kajian teori dan kerangka berpikir di atas maka diajukan hipotesis sebagai berikut: (1) Penerapan model kooperatif tipe Team Assisted Individualization (TAI) dapat meningkatkan aktivitas belajar siswa kelas VI pada pembelajaran IPA di SDN 3 Penatih; (2) Penerapan model kooperatif tipe Team Assisted Individualization (TAI) dapat meningkatkan Prestasi belajar siswa kelas VI pada pembelajaran IPA di SDN 3 Penatih.

\section{III.METODOLOGI PENELITIAN}

Lokasi penelitian ini adalah di Sekolah Dasar Negeri 3 Penatih Kecamatan Denpasar Timur Kota Denpasar. Subyek penelitian ini adalah siswa kelas VI SDN 3 Penatih Kecamatan Denpasar Timur Kota Denpasar tahun pelajaran 2016/2017 pada semester I (ganjil) dengan jumlah siswa 36 orang, yang terdiri dari 18 orang siswa Lakilaki dan 18 orang siswa Perempuan. Prosedur penelitian ini melalui 2 tahapan atau siklus yang setiap siklus berisi empat langkah yaitu: (1) perencanaan, (2) pelaksanaan tindakan, (3) observasi dan evaluasi tindakan, dan (4) Refleksi. Teknik pengumpulan data dilakukan melalui:

1) Observasi, metode observasi ini dipilih karena dalam penelitian ini dilakukan pengamatan secara langsung bagaimana aktivitas (fsikomotor dan afektif) siswa dalam proses pembelajaran IPA.

2) Test, Tes ini bertujuan untuk mengetahui capaian belajar siswa terkait materi Konduktor dan Isolator Panas pada mata pelajaran IPA. Ranah kognitif yang diukur meliputi ingatan (C1), pemahaman (C2), dan aplikasi (C3).

Indikator keberhasilan yang ditetapkan sebagai patokan atau tolak ukur keberhasilan yaitu: Pembelajaran dikatakan berhasil jika prestasi belajar mencapai KKM 60 ke atas dengan kriteria prestasi belajar tinggi ( $\geq 80$ ) dan aktivitas belajar siswa dikatakan cukup aktif jika mencapai $(\geq 60)$.

\section{HASIL PENELITIAN DAN PEMBAHASAN}

\section{Hasil Tindakan Siklus I}

a) Hasil Evaluasi Aktivitas belajar siswa pada Siklus I 
Berdasarkan hasil observasi dan analisis data yang telah dilakukan pada siklus I dapat digambarkan aktivitas belajar siswa sebagai berikut:

Tabel 4.1.

Hasil Analisis Aktivitas Belajar Siswa Kelas VI

Pada Siklus I

\begin{tabular}{cclccc}
\hline No & & Kriteria & Frekuensi & Persentase & Keterangan \\
\hline $\mathbf{1}$ & $90,00-100,00$ & Sangat Aktif & 0 & $0 \%$ & Tuntas \\
$\mathbf{2}$ & $80,00-89,99$ & Aktif & 2 & $6 \%$ & Tuntas \\
$\mathbf{3}$ & $60,00-79,99$ & Cukup Aktif & 29 & $81 \%$ & Tuntas \\
$\mathbf{4}$ & $40,00-59,99$ & Kurang Aktif & 5 & $14 \%$ & Tidak Tuntas \\
$\mathbf{5}$ & $0,00-39,99$ & Sangat Kurang Aktif & 0 & $0 \%$ & Tidak Tuntas \\
\hline & & Total & $\mathbf{3 6}$ & $\mathbf{1 0 0 \%}$ & \\
\hline
\end{tabular}

Sumber: Lampiran 8

Berdasarkan Tabel 4.1 di atas, dapat dilihat bahwa 6\% siswa tergolong pada kriteria aktif. $81 \%$ siswa cukup aktif, dan $14 \%$ siswa yang kurang aktif. Secara keseluruhan nilai rata-rata dari aktivitas belajar yang dicapai oleh siswa pada siklus I adalah $67,33 \%$ (Lampiran 8). Tingkat aktivitas siswa dapat digolongkan pada kriteria (60,00 - 79,99) cukup aktif.

b) Hasil Evaluasi Prestasi Belajar siswa pada Siklus I

Berdasarkan analisis data yang telah dilakukan, maka dapat disimpulkan hasil belajar IPA siswa sudah sesuai dengan harapan mencapai diatas KKM 60. Ini dapat dilihat dari hasil evaluasi melalui tes formatif di akhir siklus 1, capaian prestasi belajar siswa dapat dikatakan telah meningkat jika dibandingkan dengan tes awal (pra siklus) yang dilakukan. Hal tersebut dapat dilihat dari rata-rata nilai yang diperoleh oleh siswa mencapai 65,28 dan daya serap belajar siswa mencapai 65,28\% serta ketuntasan materi mencapai 81\%.Secara lebih rinci dapat disajikan pada Tabel 4.2. di bawah ini.

Tabel 4.2.

Hasil Analisis Prestasi Belajar Siswa Kelas VI

Dalam Pembelajaran IPA Pada Siklus I

\begin{tabular}{ccccc}
\hline Interval & Kualifikasi & $\begin{array}{c}\text { Banyaknya } \\
\text { Siswa }\end{array}$ & $\begin{array}{c}\text { Persentase } \\
(\mathbf{\%})\end{array}$ & Keterangan \\
\hline $90,00-100,00$ & Sangat Tinggi & 2 & 5,56 & Tuntas \\
$80,00-89,99$ & Tinggi & 17 & 47,22 & Tuntas \\
$60,00-79,99$ & Cukup & 10 & 27,78 & Tuntas \\
$40,00-59,99$ & Rendah & 7 & 19,44 & Tidak Tuntas \\
$0,00-39,99$ & Sangat Rendah & 0 & 0,00 & Tidak Tuntas \\
\hline \multicolumn{2}{c}{ J u m I a h } & $\mathbf{3 6}$ & $\mathbf{1 0 0}$ & \\
\hline
\end{tabular}




\begin{tabular}{rc}
\hline Rata-rata & 65.28 \\
Ketuntasan & $81 \%$ \\
\hline Sumber: Lampiran 9 &
\end{tabular}

Berdasarkan tabel 4.2. di atas, menunjukkan bahwa 5,65\% siswa mencapai kategori sangat tinggi. 47,22\% siswa mencapai hasil kategori tinggi. 27,78\% siswa mencapai hasil kategori cukup, dan 19,44\% siswa mencapai hasil kategori rendah.

\section{Hasil Tindakan Siklus II}

a) Hasil Evaluasi aktivitas belajar siswa pada Siklus II

Berdasarkan hasil observasi dan analisis data yang telah dilakukan pada siklus II, dapat digambarkan aktivitas belajar siswa sebagai berikut:

Tabel 4.3.

Hasil Analisis Aktivitas Belajar Siswa Kelas VI Pada Siklus II

\begin{tabular}{|c|c|c|c|c|c|c|}
\hline No & \multicolumn{2}{|c|}{ Kriteria } & \multirow{2}{*}{$\begin{array}{c}\text { Frekuensi } \\
5\end{array}$} & \multirow{2}{*}{$\begin{array}{c}\text { Persentase } \\
19,44 \%\end{array}$} & \multirow{2}{*}{$\begin{array}{c}\text { Keterangan } \\
\text { Tuntas }\end{array}$} & \multirow{2}{*}{$\begin{array}{l}\text { Sumber: } \\
\text { Lampira } \\
\text { n } 14\end{array}$} \\
\hline 1 & $90,00-100,00$ & Sangat Aktif & & & & \\
\hline 2 & $80,00-89,99$ & Aktif & 20 & $55,56 \%$ & Tuntas & Berda \\
\hline 3 & $60,00-79,99$ & Cukup Aktif & 11 & $25,00 \%$ & Tuntas & sarka \\
\hline 4 & $40,00-59,99$ & Kurang Aktif & 0 & 0 & Tidak Tuntas & \\
\hline 5 & $0,00-39,99$ & Sangat Kurang Aktif & 0 & 0 & Tidak Tuntas & \\
\hline & & otal & 36 & $100 \%$ & & $\mathrm{tab}$ \\
\hline
\end{tabular}

4.3 diatas, menunjukan bahwa 19,44\% tingkat aktivitas belajar siswa sangat aktif, $55,56 \%$ siswa kategori aktif, dan 25,00\% siswa berada pada kategori cukup aktif. Secara keseluruhan nilai rata-rata dari aktivitas belajar yang dicapai oleh siswa pada siklus II ini adalah 74,81\% (Lampiran 14). Tingkat aktivitas siswa dapat digolongkan pada kriteria $(80,00$ - 89,99) aktif.

b) Hasil Evaluasi Prestasi Belajar siswa pada Siklus II

Hasil analisis nilai rata-rata prestasi belajar IPA yang diperoleh oleh siswa mencapai 80,28 dengan ketuntasan belajar $100 \%$. Secara lebih rinci perolehan nilai tes formatif siswa disajikan pada Tabel 4.4 di bawah ini.

Tabel 4.4

Hasil Analisis Prestasi Belajar Siswa Kelas VI

Dalam Pembelajaran IPA Pada Siklus II

\begin{tabular}{ccccc}
\hline Interval & Kualifikasi & $\begin{array}{c}\text { Banyaknya } \\
\text { Siswa }\end{array}$ & $\begin{array}{c}\text { Persentase } \\
(\mathbf{\%})\end{array}$ & Keterangan \\
\hline $90,00-100,00$ & Sangat Tinggi & 14 & 38,89 & Tuntas \\
$80,00-89,99$ & Tinggi & 19 & 52,78 & Tuntas \\
$60,00-79,99$ & Cukup & 3 & 8,33 & Tuntas \\
$40,00-59,99$ & Rendah & 0 & 0,00 & Tidak Tuntas
\end{tabular}




\begin{tabular}{cccc}
$0,00-39,99 \quad$ Sangat Rendah & 0 & 0,00 & Tidak Tuntas \\
\hline J u m I a h & $\mathbf{3 6}$ & $\mathbf{1 0 0}$ \\
\hline Rata-rata & & 80,28 \\
Ketuntasan & & $100 \%$ \\
\hline Sumber: Lampiran 15 &
\end{tabular}

Tabel 4.4, menunjukan bahwa 38,89\% siswa mencapai prestasi belajar kategori sangat tinggi, 52,78\% siswa mencapai prestasi belajar tinggi, dan 8,33\% siswa mencapai prestasi belajar kategori cukup tinggi. Hasil ini menggambarkan tindakan pada siklus II bila dilihat dari sisi proses pembelajaran terlihat ada peningkatan daripada siklus I.

Berdasarkan deskripsi hasil penelitian dan pembahasan di atas, dapat dinyatakan bahwa penerapan pembelajaran Kooperatif tipe Team Assisted Individualization (TAI) terbukti meningkatkan aktivitas dan prestasi belajar siswa dalam mata pelajaran IPA kelas VI SDN 3 Penatih. Model pembelajaran kooperatif tipe TAI merupakan model pembelajaran yang cocok bagi siswa apabila guru menginginkan siswa memiliki kemampuan berkreasi, berargumentasi, mengeluarkan pendapat secara lugas, serta bertukar pikiran. Model ini juga mampu membantu siswa untuk dapat membangkitkan kepercayaan diri siswa dalam berbicara dihadapan orang banyak. Hal ini berarti hipotesis yang diajukan pada penelitian ini dapat diterima.

\section{SIMPULAN DAN SARAN}

Berdasarkan hasil analisis data seperti yang sudah diuaraiakan di atas, dapat ditarik beberapa simpulan selama kegiatan dilaksanakan dengan penerapan pembelajaran Kooperatif tipe Team Assisted Individualization (TAI). Adapun simpulan yang di ambil adalah sebagai berikut:

1) Penerapan pembelajaran Kooperatif tipe Team Assisted Individualization (TAI) dalam mata pelajaran IPA pada siswa kelas VI pada Semester I di SDN 3 Penatih tahun pelajaran 2016/2017 dapat meningkatkan aktivitas belajar siswa. Hal ini ditunjukkan oleh hasil penelitian terhadap aktivitas belajar siswa pada siklus I diperoleh nilai rata-rata sebesar 67,33 dengan persentase keaktifan 80,56\% kategori cukup aktif, mengalami peningkatan nilai rata-rata aktivitas belajar pada siklus II menjadi 74,81 dengan persentase keaktifan 55,56\% pada kategori aktif.

2) Penerapan pembelajaran Kooperatif tipe Team Assisted Individualization (TAI) dalam mata pelajaran IPA pada siswa kelas VI pada Semester I di SDN 3 Penatih 
tahun pelajaran 2016/2017, dapat meningkatkan prestasi belajar siswa. Hal ini ditunjukkan oleh capaian prestasi belajar siswa pada siklus I mencapai rata-rata sebesar 65,28 dengan ketuntasan 81\%, meningkat pada siklus II rata-rata nilai yang dicapai 80,28 dengan ketuntasan $100 \%$ atau meningkat sebesar $19 \%$.

Sehubungan dengan simpulan diatas, maka dapat dikemukakan beberapa saran sebagai berikut:

1) Kepada siswa kelas VI SDN 3 Penatih, dihimbau pada saat mengikuti pelajaran IPA agar menyiapkan diri sebaik mungkin dengan cara membaca/mempelajari materi pelajaran IPA tersebut sebelum pelajaran dimulai, sehingga ketika proses belajar dikelas berlangsung siswa lebih cepat memahami penjelasan guru dan dapat mengajukan berbagai pertanyaan dan atau meminta penjelasan kepada guru mengenai meteri pelajaran yang belum dimengerti.

2) Kepada guru hendaknya memperhatikan perkembangan siswa agar metode pembelajaran yang dipilih dapat efektif dan efisien sehingga siswa tidak cepat bosan dan proses pembelajaran dapat mencapai tujuan yang diharapkan.

3) Hasil penelitian ini dapat dijadikan sebagai acuan untuk penelitian berikutnya. Penerapan pembelajaran Kooperatif tipe Team Assisted Individualization (TAI) patut dipertahankan dan bila perlu ditingkatkan dalam upaya meningkatkan aktivitas dan prestasi belajar siswa.

\section{DAFTAR PUSTAKA}

Jacobs,G.M., Lee, G.S, dan Ball, J. 1996. Learning Cooperative Levia Cooperatif Learning: A Sourebook of Lesson Plans for Teacher Edu-cation on Cooperatif Learning. Singapore: SEAMEO Regional Language Center.

Kurniawati, Mei. 2012. Penerapan Model Pembelajaran Kooperatif Tipe TAI (Team Assisted Individualization) untuk Meningkatkan Keaktifan dan Prestasi Belajar Matematika Siswa Kelas V MI YAPPI Mulusan Paliyan Gunungkidul. Skripsi. Yogyakarta: Fakultas Tarbiyah dan Keguruan Universitas Islam Negeri Sunan Kalijaga

Novilia, Winda. 2014. Penerapan Model Pembelajaran Kooperatif tipe (TAI) Team Assisted Individualization untuk Meningkatkan Keaktifan Belajar Matematika pada siswa kelas IV SD Negeri Mojosari Karanggede Boyolali. Naskah Publikasi. Surakarta: Fakultas Keguruan dan Ilmu Pendidikan Universitas Muhammadiyah.

Slavin, Robert E. 1995. Cooperative Learning : Theory, Research, and Practice. Boston: Allyn and Bacon.

Sudarta, I Wayan. 2010. Pembelajaran Kooperatif STAD dengan Media Laptop dan LCD 
Program Animasi Sebagai Inovasi Pembelajaran untuk meningkatkan Aktivitas dan Prestasi Belajar Matematika Siswa Kelas IXa SMP Negeri 4 Nusa Penida Tahun Pelajaran 2010/2011. Penelitian Tindakan Kelas. Klungkung: SMP N 4 Nusa Penida.

Tim Bina Karya Guru. 2008. IPA SD untuk Sekolah Dasar Kelas VI. Jakarta: Penerbit Erlangga. 